\title{
COCONUT AGRICULTURAL RESEARCH IN THE PHILIPPINES ITS HISTORY, TECHNOLOGICAL ADVANCES AND FUTURE TARGETS
}

\author{
by ${ }_{\text {Dr. SEVERINO S. MAGAT }}{ }^{1}$
}

\begin{abstract}
The paper deals with selected aspects of agricultural research on coconuts in the Philippines as follows : (a) a historical review; (2) agricultural research system; (3) scientific and technological advances and findings; and (4) future development oriented targets.

Recognizing the need to support the development of the coconut industry under a sustainable and profitable coconut farming environment, the R \& D Thrusts of agricultural research centers on : 1) Varietal Improvement; 2) Cultural and Fertilizer Management (with emphasis on Integrated Soil Fertility Management; 3) Integrated Crop Protection; 4) Cadang-cadang disease control; 5), Processing and Utilization of Coconut Wood; and 6) Technical Support Services and Advisory Development.
\end{abstract}

Significant breakthroughs during the past 18 years are briefly highlighted in the paper.

\section{INTRODUCTION}

Tle coconut (Cocos nucifera L.) is one of the major crops of the Philippines. It accounts for $3.2 \mathrm{M}(1990)$ or $30 \%$ of the country's total agricultural land. Its products, as copra, oil, copra cake, dessicated coconut, charcoal and coir had been the top dollar earners since 1976 to 1986 (except in 1980) from among the others, viz. minerals, sugar and forest products. From 1979 to 1988, the value of coconut exports averaged $\$ 700 \mathrm{M} /$ year. The Philippines is still the world's No. 1 supplier of coconut products accounting for about $70 \%$ of the aggregate world export. Moreover, socio-economically about $18 \mathrm{M}$ Filipinos or a third of the entire population is directly or indirectly dependent on the coconut industry as their means of livelihood. Hence, research on the agricultural aspects to accelerate development should be relevant.

\section{HISTORICAL BACKGROUND}

Research on coconut is known to have been undertaken as early as 1950's and prior to the creation of the PHILIPPINE COCONUT RESEARCH INSTITUTE (PHILCORIN). In April 1965, there were more than ten (10) government agencies undertaking various researches on coconut. Because of this multiplicity of efforts results were unnecessary duplication, hence wastage of resources. Research was mostly directed towards curiosity rather than solving practical field problems. Operating under the National Science Development Board (NSDB), PHILCORIN hoped to coordinated these research efforts. On February 6, 1966, an area of 189 hectares located at Bago-Oshiro, Davao City (now Davao Research Center) was leased from the Bureau of Plant Industry (BPI) and operations commenced in March 1967. The objectives pursued then were: 1) to conduct scientific researches and investigations on the botanical and genetical aspects in coconut improvement, agronomical problems relating to coconut culture, control of pests and diseases of coconuts including cadang-cadang; 2) compile scientific information and technological researches; and 3) train people for the development of the coconut industry.

\footnotetext{
${ }^{1}$ Research Manager, Agricultural Research Management Department Philippine Coconut Authority, Quezon Cirde Difiman, Quezon City. Metro Manila.
} 
Despite its meager resources, the institute was able to commence research on important issues with the aid of external finance. During the period 1963 to 1970 United Nations Development Programme (UNDP) consultants submitted proposals for the improvement and development of the Institute, but it was only in 1 January 1971 that the UNDP project "Coconut Research and Development" was launched. The long-range objective of the project was to guide and strengthen coconut research activities and to assist the Govemment in developing and applying, on a national scale, a coordinated prograrn of activities aimed at improving coconut production and primary processing. With the expansion of research activities under the FAO-UNDP project, a 500-hectare station located at San Ramon Zamboanga City was acquired through Presidential Proclamation No. 1025, dated June 1972. Research projects were then carried out at the Research Centers of Davao and Zamboanga.

In June 1973 by virtue of PD 232, the Philippine Coconut Authority (PCA) was established and unified the efforts of PHILCORIN, Philippine Coconut Administration (PHILCOA) and Coconut Coordinating Council (CCC) to provide leadership towards the development of the coconut industry. The functions and resources of the old PHILCORIN was taken over by Agricultural Research Department (ARD). The Department likewise maintained the role of the local counterpart to the FAO/UNDP's Coconut Research and Development Project in the areas of coconut breeding, agronomy and nutrition, integrated pest control, primary processing, timber utilization and extension training. The Department was elevated to the Agricultural Research Branch in 1976. At the same year, the BPI-owned Guinobatan Experiment Station (GES) was turned over to the PCA. Subsequently, the Agricultural Research Program was pursued under the auspices of the Agricultural Research Branch by the three (3) research centers (Davao, Albay and Zamboanga).

Then in 1981 during the PCA reorganization, the Agricultural Research and Agricultural Development Branches were merged and became the Agricultural Research and Development Branch under the Administration of a Deputy Administrator (DA). Later in November 1983, the Agricultural Research Division was created to provide technical services on agricultural research to the office of the DA. Later, in October 1985, the Agricultural Research Management Department was also created, to coordinate, monitor and evaluate the agricultural research efforts, operate a plant and soil analysis laboratory; and maintain effective research linkages with other government and private institutions.

\section{AGRICULTURAL RESEARCH SYSTEM}

Under the system, the Agricultural Research and DevelopmentBranch (ARDB) has the overall control and direction of three (3) national research centers and one support department that provides support and advisory services to research and field operations activities of the authority.

\section{A. AGRICULTURAL RESEARCH MANAGEMENT DEPARTMENT (ARMD)}

The Agricultural Research Management Department is based at the Central Office, Diliman, Quezon City. This is manned by a Department Manager and supporting staff. There are two Divisions directly under it, viz. the Agricultural Research Division (ARD) and the Tissue Analysis Laboratory (TAL). The ARMD is tasked to do the following functions:

1) To review/oversee all functions and activities in accordance with the work programs and objectives of the Department;

2) To advise, assist the Deputy Administrator, ARDB on matter involving policies and programs in agricultural research relative to productivity programs;

3) To establish, sustain linkages with other agencies on related matters; 
4) To develop a strong in-house capability for technical/consultative services to agricultural research planning and development;

5) To provide Biometric and computer advisory service

6) To provide Laboratory Analytical Services.

7) To provide consultancy and advisory services on crop agronomy and fertilizer management.

\section{B. ALBAY RESEARCH CENTER (ARC)}

The Center, with an area of 63 hectares is situated in Banao, Guinobatan, Albay, 26 kilometers from Legaspi City. It is 505 kilometers south of Metro Manila. The station is located 100 meters above sea level; with an average annual rainfall of 3,600 mm, having a wet type climate $(10.5$ wet months). The Center is supported by three technical Divisions (Virology-Biochemistry, Entomology-Epidemiology and Tissue Culture). namely :

It is tasked to conduct research on the cadang-cadang malady of the coconuts, with objectives

1) To identify and understand the causative factors of the disease;

2) To monitor geographical distribution including surveys of flora and insect fauna in affected areas;

3) To develop meastires for its control and possibly eradication; and

4) To develop Tissue Culture as a micropropagation technique to massproduce desirable planting materials.

\section{DAVAO RESEARCH CENTER (DRC)}

This is located at Bago-Oshiro, Davao City. It is situated at the footslopes of Mt. Apo and is approximately 18 kilometers from the City proper. The area comprises about 189 hectares; 120-140 meters above sea-level with an average annual rainfall of $2,415 \mathrm{~mm}$ having a humid type climate (9 wet months). The Center is tasked to :

1) Generate improved cultural management practices and fertilization (inorganic and/or organic); intercropping (annuals, biennials or perennials), animal-raising under coconuts; integrated soil fertility management (ISFM).

2) Conduct on-farm field fertilizer trials (OFFTs).

3) Generate practical, economical and socially acceptable schemes (integrated approach) to control pests and diseases, taking into consideration LISA (Least Input Sustainable Agriculture).

\section{ZAMBOANGA RESEARCH CENTER (ZRC)}

This is a 500 hectare area located at San Ramon, Zamboanga City, 21 kilometers; from the City proper. It is situated 3-6 meters above sealevel, with about 1,700 $\mathrm{mm}$ annual rainfall, having a humid type climate ( 9 wet months). It deals on : 
1) Identification of cultivars through preprospection surveys (commercial and saleable varieties/population);

2) Establishment/maintenance of genetic blocks of local and foreign population;

3) Development of appropriate breeding techniques and breeding of promising populations and hybrids;

4) Ultimately to develop synthetic coconut varieties.

5) Processing and utilization of cocowood for high value products and marketable by-products.

\section{SCIENTIFIC AND TECHNOLOGICAL ADVANCES AND FINDINGS}

\subsection{Varietal Improvement}

* Establishment at the Zamboanga Coconut Research Center of a total of 83 coconut populations ( 22 dwarfs, 54 talls, 7 line collections and 42 hybrid crosses under tests).

* Development of the PCA 15-1 (Catigan dwarf x Laguna tall), the first local hybrid recommended for nationwide planting, followed by PCA 15-2 (Malayan Red Dwarf $x$ Tagnanan), PCA 15-3 (Malayan Red Dwarf x Baybay).

\subsection{Cultural and Fertilizer Management}

* Fertilizer application results in flowering of some local talls and hybrids in 42-47 months and 24-30 months, respectively from field-planting, under very favorable environments of Davao and Zamboanga.

* Beneficial effects of chlorine on copra weight of nut and copra yield, as a control of leaf spot/blight diseases of coconut; $\mathrm{KCI}, \mathrm{NH} 4 \mathrm{C} 1$ and $\mathrm{NaCl}$ (common salt) as effective sources of chlorine.

* A guide on the chlor'ine requirement of coconut from nursery to bearing stage; and critical and optimum leaf nutrient levels for foliar diagnosis have been identified.

* Use of foliar diagnosis in effecient fertilizer recommendation and identification of N, C1 $\mathrm{K}$ and $\mathrm{S}$ as, the major nutrient deficiencies in the coconut areas of the country.

* Production of toddy (coconut sap) and nut from same spathes, trees and cropping period is feasible.

\subsection{Crop Protection}

* Under field conditions, green muscardine fungus (GMF) showed high percentage (35\%) of infectivity against rhinoceros beetle larvae at 4 months after initial application.

* Other potential bio-control agents are as follows:

(a) Apanteles tirathabae (larval parasitoid) against coconut spike moth.

(b) Beauveria bassiana (entomophagous fungus) against spike moth, hispid beetle and leafminer. 
(c) Baculovirus of oryctes rhinoceros

(d) Bacillus thuringenesis against slug caterpillar

(e) Eucanthecon a furcellata, a predator of slug caterpillar (can be mass-produced easily).

* So far, positive test to coconut cadang-cadang virmd (CCCVd) is best achieved when palms are individually assayed by polycrylamide gel electrophoresis (PAGE) and Molecular Hybridization (MHA).

* CCCVd can be transmitted by pollen and seednut.

\subsection{Coconut Wood Utilization}

* The PCA-TUD (ZRC) designed solar heat and heat exchanger for drying of cocolumber is capable of increasing the kiln temperature to $44^{\circ} \mathrm{C}$ during sunny days and $50^{\circ} \mathrm{C}$ (through heat exchanger) with a drying time of 6 days for $25 \mathrm{~mm}$ boards and production of $540 \mathrm{~kg}$ charcoal per setting.

* Varnish and clear gloss lacquer are suitable for cocowood clear finishing.

* CCA-treated external housing components and electric poles arc still in sound condition (without termite damage) after 10 years of service.

* Sodium pentachlorophenate based fungicides (Basilit PN and Pentabrite) arc best control against stain fungi and molds of freshly sawn lumber.

* Cocowood parquet are high value product from offcuts and slabs of coconut sterns

* Furnitures and ballusters are high - value products of cocowood.

\section{FUTURE DEVELOPMENT-ORIENTED TARGETS}

\subsection{Varietall Improvement :}

(1) New improved planting materials (3-5) recornmended for nationwide use in sustainable areas for replanting,

(2) The parental populations of 6 good combining talls to commence flowering, hence, the first stage of bulking and open-pollination can take place to produce the first generation PCA Syn Var 001;

(3) Complete the evaluation of the vegetative assets (roots, trunk and anchorage) of promising populations;

(4) Screen and select few populations/hybrids and advanced generation for resistance to diseases (i.e. Phytophthora budrot/fruit rot, etc.)

\subsection{Cultural and Fertilizer Management :}

(1) Appropriate fertilization guide for coconut hybrids and local cultivars under various climatic conditions; 
(2) Alternative fertilizer sources or less expensive fertilizers as organic manures and fertilizers;

(3) Suitable varieties of coffee and corn varieties as intercrop for coconut;

(4) An econornically sound and ecologically appropriate cropping pattern, of corn and peanut, and coffee under coconut intercropping systems; ,

(5) A viable technology on the combined toddy and nut productions using same spathes of palms of talls and hybrids;

\subsection{Integrated Crop Protection :}

(1) Practical assessment methods for economic damage threshold levels for major pests and diseases for pest management;

(2) Extensive field application of fungus pathogens, virulent virus strains and parasitoids against major insect pests and diseases;

(3) Mass production of at least 1,000 kg of GMF covering a 500 ha pilot area;

(4) Economical, viable and ecological sound integrated control of major pests and diseases.

\subsection{Cadang-cadang Disease Control :}

(1) Identified tolerant coconut palms as source of planting materials for replanting cadang-cadang devastated areas;

(2) Field-sanitation techniques to minimize disease spread;

(3) Identified vector(s) or agent(s) of the disease through transmission and epiderniological studies;

(4) Identified mild strains for cross protection studies to induce immunity resistance;

(5) Updated distribution of cadang-cadang in the Philippines with emphasis in provinces near the border of cadang-cadang affected areas in Quezon; Surigao and nearby islands; Marinduque, Laguna and Leyte.

\subsection{Tissue Culture Technique :}

(1) Established workable tissue culture laboratory and screen-house facilities;

(2) Adequately trained staff;

(3) Basic and applied results leading to the researches for clonal propagation techniques to mass-produce desirable planting materials.

\subsection{Cocowood Processing and Utilization :}

(1) A technology package for converting logging and sawmilling wastes/residues into wood-wool-cement boards and sawdust as housing components.

(2) Technologies on kiln drying and finishing schedules to stabilize cocowood for the manufacture of furnitures, parquet, joineries and other high value wood products; 
(3) Economic and practical cocowood preservation techniques to improve durability of low-cost houses;

(4) Effective locally available wood preservatives and treatment methods for coconut timber used in ground content and exposed conditions as housing materials and electric poles;

(5) A viable technology on commercial production of cocowood finished products for domestic and export markets.

\section{REFERENCES}

ABAD, R. G.(1983) Coconut Pests and Diseases in the Philippines. Coconuts Today 1(2): 119-132.

ARDB (1991) Agricultural Research: An Overview. Philippine Coconut Authority, Diliman, Quezon City. 70 p.

MAGAT, S. S., MARGATE, R. Z. and HABANA, J. A. 1988. Effects of increasing rates of sodium chloride (common salt) fertilization on coconut palms grown under an inland soil (Tropudalfs) of Mindanao, Philippines. Oleagineux 43(1): 13-17.

MAGAT, S. S. and MARGATE, R. Z.(1989) The Nutritional Deficiencies and Fertilization of Coconut in the Philippines. Res. and Dev. Technical Report No. 2 (February 1989), PCA, Diliman, Quezon City, 73 p.

MAGAT, S. S. and MARGATE, R. Z. (1990) The Chlorine Needs of Coconut. CORD (Coconut Res. and Dev.) 7(1): 30-51. Asian and Pacific Coconut Community, Jakarta, Indonesia

PALOMAR, R. N. (1990) Utilization of Coconut Wood in the Philippines. R \& D Tech. Report No. 3 (October 1990). PCA, Diliman, Quezon City. 80 p.

PCA.(1987) Agricultural Research Annual Report, 1986. Agricultural Research and Development Branch. Diliman, Quezon City. 157 p.

PCA. (1988) A Report on the Nationwide Performance of foreign hybrids tested in the Philippines by the PCA, 19771987. Research and Development Technical. Report No. 1 (Aprii 1988) 66 p.

PCA. (1990) Agricultural Research Annual Report, 1989. Agricultural Research and Development Branch. Diliman, Quezon City. 194 p.

PCA,(1990)Coconut Agricultural R \& D Program (10-yr). Agricultural Research and Development Branch, Diliman, Quezon City. 128 p.

SANTOS, G. A., BAHALA, R. T., CANO, S. B. and DELA CRUZ, B. V. (1986) Vield and Agronomic traits of four variety hybrids and some local tall populations in the Philippines. Oleagineux 41(4): 269-280. 